\section{Surgical Treatment of Bisphosphonate- Related Osteonecrosis of the Jaws with the Use of Buccal Fat Pad: Case Report}

\author{
Luiz Fernando Mathias Duarte, Kleber Alonso, Elaine Cristina Basso, Luciano
} Lauria Dib
Department of Stomatology, UNIP - Universidade Paulista, São Paulo, SP, Brazil

Correspondence: Luiz Fernando Mathias Duarte, Alameda dos Arapanés 419, ap 105, Moema, 04524-000 São Paulo, SP, Brasil. Tel: +55-11-998242933/+55-16-99155-3169. e-mail: luizfernandoduarte@hotmail.com

\begin{abstract}
Bisphosphonate-related osteonecrosis of the jaws (BROJ) has been described since 2003 as an adverse effect of bisphosphonate medications. These drugs act on the vasculature and bone remodeling, mainly on osteoclastic activity and can cause areas of necrotic bone exposure. Treatment for the BROJ is not yet defined, but surgical treatment is one of the forms proposed, which may cause oral deformities like sinus communication in some cases. In situations like this the buccal fat pad is an important alternative for coating nasal-oral communications, due its large blood supply, elasticity, absence of restriction by age and safety. This paper presents the case of a 58-year-old woman with BROJ in the left maxilla caused by the use of zoledronic acid for metastatic breast cancer. The extensive necrotic bone area was surgically removed resulting in oral sinus communication. A buccal fat pad was used to cover the defect. More studies should be performed regarding the treatment of BROJ but, if necessary, a buccal fat pad flap could be an alternative to solve nasal-oral communications related to BROJ.
\end{abstract}

Key Words: bisphosphonate, osteonecrosis of the jaws, buccal fat pad.

\section{Introduction}

Osteonecrosis of the jaws is a disease that affects the maxilla and mandible due to reduced blood supply. The main sign of this disease is necrotic bone exposure with or without suppuration or pain (1).

Several may be the causes of osteonecrosis, such as radiation, infection, surgical trauma and others. Over the past few years, a new cause of osteonecrosis has been described as a serious effect, caused by widespread use of drugs based on bisphosphonates, coming up with a specific denomination of bisphosphonate-related osteonecrosis of the jaws (BROJ) (2).

Bisphosphonates are drugs used in oncology treatments and metabolic disorders involving the skeletal system, due to its bone resorption inhibition properties (3). The most common forms are alendronate, administered orally for osteoporosis control, and zoledronic acid, administered intravenously mainly for patients with metastatic bone cancer (4).

Risk factors for development of necrosis may be related to the nature of the drug, local and systemic factors, as well as the potency and duration of medication (4).

However, the symptoms and radiographic findings may be similar to other necrotizing and inflammatory conditions such as osteoradionecrosis and osteomyelitis. Physiopathologic differences of the bisphosphonates osteonecrosis may improve prevention and treatment protocols (5).

The American Association of Oral and Maxillofacial
Surgeons (AAOMS) suggests treatment strategies like the use of $0.12 \%$ chlorhexidine mouthwash, systemic antibiotics, and surgical procedures such as curettage and bone resection (6). Other treatments have also been used, such as the bone morphogenetic protein 2 (BMP2), platelet-rich plasma (7) and hyperbaric oxygenation therapy, but without proven results $(6,8)$. In 2014 the AAOMS updated their considerations about the bisphosphonates osteonecrosis, considering as treatment goals for risk patients the prioritization and support of oncology treatment and maintaining the quality of life for those patients (9). When chosen as treatment forms, surgical methods may cause major jaw defects, resulting in possible oral-sinus communications.

The oral-sinus communications are described as pathological conditions of the oral cavity and maxillary sinus due to loss of hard and soft tissues (10). Other conditions that can lead to problems of this nature are, in most cases, complicated extractions, jaw tumor resection, cyst removal, sinus lifting, trauma and peri-implantitis. To solve these defects, several techniques are reported in the literature, like local flaps (palate or buccal) and distance flaps (tongue temporal muscle, Bichat's buccal fat pad) $(10,11)$.

The use of the buccal fat pad in oral sinus communications caused by BROJ is not much reported in the literature. However some authors have described the advantages and positive results of this technique in cases of BROJ (12). 
Several studies were performed on the structure and advantages of buccal fat pad in oral reconstruction $(13,14)$. What for many years had been considered only as a limited facial structure and surgical disorder (15) is now considered a useful structure for covering defects in the palatal region or oral mucosa, closure of oronasal problems, covering of bone grafting surfaces and post-traumatic defects reconstruction. The main advantages of using pedicled buccal fat pad are its great blood supply, elasticity, absence of restriction by age and safety (16). This paper pesents an unusual treatment of BROJ in a female patient treated by surgical procedure using a buccal fat pad where the bone defect caused by the necrotic osteotomy resulted in oral-sinus communication.

\section{Case Report}

A 58-year-old female patient of Japanese origin, nonsmoking and non-alcohol drinker, was referred to a private oral medicine clinic complaining of pain in the left maxilla where a tooth extraction had been performed 3 months before by her dentist. On clinical examination it could be observed exposed necrotic tissue and purulent secretion in bisphosphonate medication for 6 months by the oncologist.

Surgery was performed in a hospital under general anesthesia. During the procedure, while performing the mucoperiostal replacement, the exposure of the necrotic bone area revealed larger necrotic area than previously noticed during the first examination of the oral cavity (Fig. 1B). The resection of all necrotic bone portion resulted in oronasal communication causing a middle-sized maxillary defect. Thus, due to the extension of the defect and its location, it was chosen to use oral fat pad to close the communication. The release of the oral fat tissue and its replacement above the defect was sufficient to cover all the communication between the oral and sinusal cavities. The tissue support and the wide vascularization of the fat tissue allowed a satisfactory local repair. (Fig. 1C). First intention wound healing resulted in a post-surgical area completely closed 3 weeks after the procedure (Fig. 1D). After three months of antibiotic therapy and follow-up, a panoramic radiograph showed tissue repair, despite the absence of bone tissue (Fig. 1E). The clinical aspect of the mucosa was of healthy tissue without fistulas and radiographic images showed normal healing process as well. No postoperative intercurrence or symptoms was observed. The patient returned to her dental clinician for endodontic and prosthetic procedures needed in other teeth (Fig. 1F). Follow up of the patient has shown no bone exposure or symptoms associated with the operated area.

\section{Discussion}

This case reports the occurrence of BROJ in patient
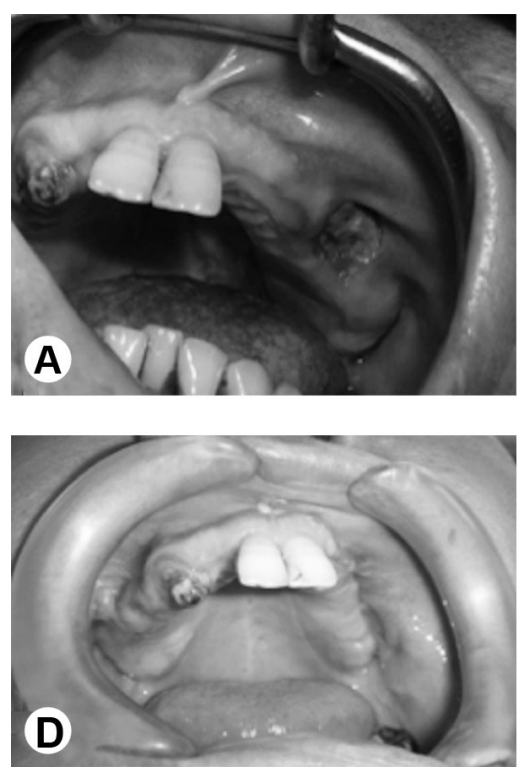
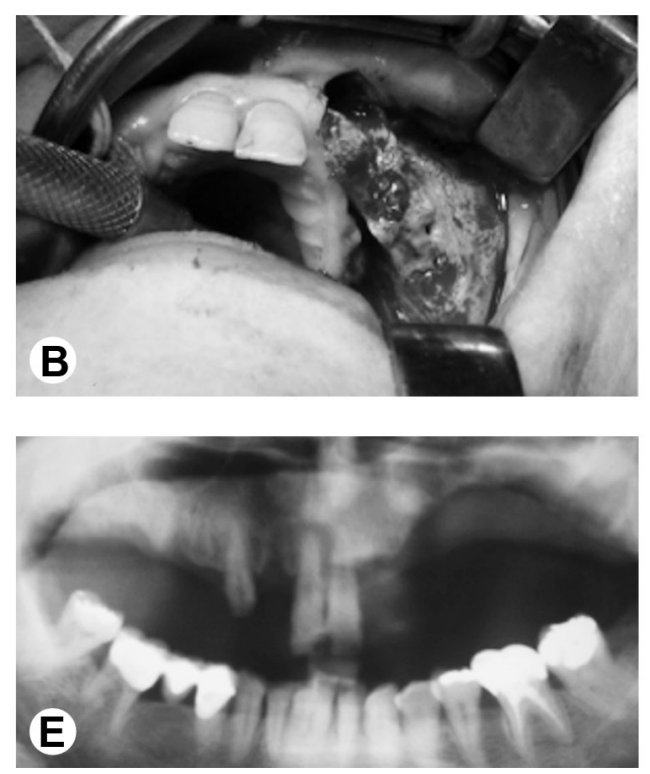

Figure 1. A: Initial aspect of the necrotic area. B: Extension of the necrotic area beyond the initially exposed area. C: Repositioning of the buccal fat pad filling the entire extent of the defect with viable tissue and bleeding. D: After first-intention suture, it is possible to observe a complete closure of the defect 3 weeks postoperatively. E: Panoramic radiograph showing the operated area without signs of bone necrosis or infectious processes. F: Final aspect of the region with no fistulas or secretion, allowing a prosthetic rehabilitation. 
user of zoledronic acid due to a metastatic breast cancer.

The literature reports differences in the occurrence of BROJ comparing the potency between oral and intravenous bisphosphonate. In accordance with the present case, in which the patient used intravenous zoledronic acid, other authors have reported a greater potential of intravenous medications for triggering the BROJ because of its higher power of action $(17,18)$. According to Marx $(19)$, the occurrence of BROJ associated with intravenous medication is higher in the mandible than in the maxilla at a 2:1 ratio.

The fact that the patient had a tooth extracted at the site of BROJ led us to believe that this procedure has been the 'trigger' to the disease. There have been reports of tooth extraction as the main factor to the occurrence of bisphosphonates-related osteonecrosis at sites with low bone turnover capacity due to the presence of bisphosphonates, causing osteoclastic activity inhibition interfering on the tissue healing (19).

A treatment protocol for BROJ has not yet been established, but different forms of management have been recommended $(6,8)$. In this case, surgical resection of the necrotic bone was chosen, with antibiotic therapy based on oral clindamycin and daily mouthwash with chlorhexidine at $0.12 \%$. Ruggiero et al. (1) also recommend this approach when patient presents necrosis with exposed bone, pain, infection with fistula and possibility of pathological fractures. As reported by Marx (19), bone resection in case of maxilla BROJ is due to the fact that the disease gets more severe in alveolar bone, which is more prevalent in that region. The same author reports that the majority of jaw resections can result in sinus-oral communication, as occurred in this case.

Few reports of BROJ mention the use of buccal fat pad for closing jaw defects created after necrotic tissue resection (12). Most studies that present this technique show the advantages of using the buccal fat pad, emphasizing the tissue elasticity that allows covering medium size defects, its large blood supply and soft tissue support allowing a fast epithelialization and the safety of technique when well indicated and performed by an experienced surgeon $(13,16,20)$.

Despite the benign resolution of the case, the choice for surgical treatment of BROJ should be done with criterion because the literature reports many cases with serious consequences: mutilation, pain and systemic sequels resulting from continued suppuration of necrotic areas $(17,19)$.

As the etiology of BROJ has not been well established, prophylactic and preventive strategies are essential for patients receiving bisphosphonates. Good results are difficult to be achieved so the treatment modality should be rigorously selected.
Surgical treatment using the buccal fat pad may be an important measure when oral communication occurs, avoiding more severe consequences that the absence of bone healing would produce.

\section{Resumo}

Osteonecrose dos maxilares por bifosfonatos (OMB) tem sido descrita desde 2003 como um efeito adverso dos medicamentos bifosfonatos. Essas drogas atuam sobre a vascularização e remodelação óssea, principalmente na atividade osteoclástica, podendo gerar áreas de exposição óssea necrótica. 0 tratamento para a doença ainda não é definido, mas o tratamento cirúrgico é uma das formas preconizadas que, em algumas situações podem ocasionar deformações orais como as comunicações buco-sinusais. Em situações como esta o tecido adiposo bucal é uma alternativa importante para o recobrimento da comunicação oro-nasal, devido ao seu grande suprimento sanguineo, elasticidade, ausência de restrição pela idade e segurança. Este trabalho apresenta um caso clínico de paciente de 58 anos do sexo feminino, portadora de $\mathrm{OMB}$ em maxila esquerda pelo uso de ácido zoledrônico para câncer metastático. A extensa remoção da porção óssea necrótica resultou em fístula buco-sinusal. 0 retalho do tecido adiposo bucal foi utilizado para cobrir o defeito. Mais estudos devem ser realizados com relação ao tratamento de $\mathrm{OMB}$, no entanto, se necessário, o retalho de tecido adiposo bucal poderia ser uma alternativa para resolver a comunicação oro-nasal relacionada à OMB.

\section{Acknowledgements}

The authors are grateful to Brazilian funding agency CAPES for the financial support.

\section{References}

1. Ruggiero SL, Fantasia J, Carlson E. Bisphosphonate-related osteonecrosis of the jaw: background and guidelines for diagnosis, staging and management. Oral Surg Oral Med Oral Pathol Oral Radiol Endod. 2006;102:433-441.

2. Marx RE. Pamidronate (Aredia) and zoledronate (Zometa) induced avascular necrosis of the jaws: a growing epidemic. J Oral Maxillofac Surg. 2003;61:1115-1117

3. Assael LA. New foundations in understanding osteonecrosis of the jaws. J Oral Maxillofac Surg. 2004;62:125-126.

4. Landesberg R, Cozin M, Cremers S, Woo V, Kousteni S, Sinha S, et al.. Inhibition of oral mucosal cell wound healing by bisphosphonates. J Oral Maxillofac Surg 2008;66:839-847.

5. Franco-Pretto $E$, Pacheco M, Moreno A, Messa O, Gnecco J. Bisphosphonate-induced osteonecrosis of the jaws: clinical, imaging, and histopathology findings. Oral Surg Oral Med Oral Pathol Oral Radiol. 2014;118:408-417.

6. Advisory Task Force on Bisphosphonate-Related Ostenonecrosis of the Jaws, American Association of Oral and Maxillofacial Surgeons. American Association of Oral and Maxillofacial Surgeons position paper on bisphosphonate-related osteonecrosis of the jaws. J Oral Maxillofac Surg. 2007;65:369-376.

7. Curi MM, Cossolin GS, Koga DH, Zardetto C, Christianini S, Feher O, et al.. Bisphosphonate-related osteonecrosis of the jaws - an initial case series report of treatment combining partial bone resection and autologous platelet-rich plasma. J Oral Maxillofac Surg. 2011;69:24652472.

8. Migliorati CA, Casiglia J, Epstein J, Jacobsen PL, Siegel MA, Woo SB. Managing the care of patients with bisphosphonate-associated osteonecrosis: an American Academy of Oral Medicine position paper. J Am Dent Assoc. 2005;136:1658-1668. Review. Erratum in: J Am Dent Assoc. 2006;137:26.

9. Ruggiero SL, Dodson TB, Fantasia J, Goodday R, Aghaloo T, Mehrotra $B$, et al.. American Association of Oral and Maxillofacial Surgeons. American Association of Oral and Maxillofacial Surgeons position 
paper on medication-related osteonecrosis of the jaw--2014 update. J Oral Maxillofac Surg. 2014;72:1938-1956.

10. Abad-Gallegos M, Figueiredo R, Rodríguez-Baeza A, Gay-Escoda C. Use of Bichat's buccal fat pad for the sealing of orosinusal communications. A presentation of 8 cases. Med Oral Patol Oral Cir Bucal. 2011;16:e215-e219.

11. Poeschl PW, Baumann A, Russmueller G, Poeschl E, Klug C, Ewers R. Closure of oroantral communications with Bichat's buccal fat pad. J Oral Maxillofac Surg. 2009;67:1460-1466.

12. Gallego L, Junqueira L, Pelaz A, Hernando J, Megías J. The use of pedicled buccal fat pad combined with sequestrectomy in bisphosphonate-related osteonecrosis of the maxilla. Med Oral Patol Oral Cir Bucal. 2012;17:e236-e241.

13. Tideman $\mathrm{H}$, Bosanquet $A$, Scott J. Use of the buccal fat pad as a pedicled graft. J Oral Maxillofac Surg. 1986;44:435-440.

14. Stuzin JM, Wagstrom L, Kawamoto HK, Baker TJ, Wolfe SA. The anatomy and clinical applications of the buccal fat pad. Plast Reconstr Surg. 1990;85:29-37.

15. Rapidis AD, Alexandridis CA, Eleftheriadis E, Angelopoulos AP. The use of the buccal fat pad for reconstruction of oral defects: review of the literature and report of 15 cases. J Oral Maxillofac Surg. 2000;58:158-
163.

16. Ashtiani AK, Fatemi MJ, Pooli AH, Habibi M. Closure of palatal fistula with buccal fat pad flap. Int J Oral Maxillofac Surg. 2011;40:250-254.

17. Marx RE, Sawatari Y, Fortin M, Broumand V. Bisphosphonate-induced exposed bone (osteonecrosis/osteopetrosis) of the jaws: risk factors, recognition, prevention and treatment. J Oral Maxillofac Surg. 2005;63:1567-1575

18. Diel IJ, Fogelman I, Al-Nawas B, Hoffmeister B, Migliorati C, Gligorov J, et al.. Pathophysiology, risk factors and management of bisphosphonate-associated osteonecrosis of the jaw: Is there a diverse relationship of amino- and non-aminobisphosphonates? Crit Rev Oncol Hematol. 2007;64:198-207.

19. Marx RE. Reconstruction of defects caused by bisphosphonate-induced osteonecrosis of the jaws. J Oral Maxillofac Surg. 2009;67:107-119.

20. Gröbe A, Eichhorn W, Hanken H, Precht C, Schmelzle R, Heiland M, et al.. The use of buccal fat pad (BFP) as a pedicled graft in cleft palate surgery. Int J Oral Maxillofac Surg. 2011;40:685-689.

Received December 14, 2013 Accepted March 23, 2015 